\author{
Козловская Наталья Владимировна
}

\title{
ПСИХОЛОГО-ПЕДАГОГИЧЕСКИЕ ФАКТОРЫ ФОРМИРОВАНИЯ СКЛОННОСТИ ПОДРОСТКОВ К ВИКТИМНОМУ ПОВЕДЕНИЮ
}

В статье рассматривается проблема виктимности и причины ее возникновения в подростковом возрасте. Обосновывается актуальность изучения данного феномена. Обобиаются результаты научных работ по проблеме виктимности и виктимного поведения. Приводятся результаты эмпирического исследования, направленного на выявление сочиально-психологических детерминант формирования в подростковом возрасте склонности к виктимному поведению. Показано, что проявления виктимного поведения у подростков иметот различия в зависимости от степени его реализованности, что склонность к виктимному поведению может быть обусловлена представлениями подростков о спечифических стратегиях семейного воспитания, используемых родителями, а также индивидуально-психологическими особенностями самих подростков, прояеляючимися на эмоциональном, личностном и поведенческом уровнях.

Ключевые слова: виктимность, процесс виктимизации, виктимное поведение, подростковый возраст, стили семейного воспитания, индивидуально-психологические особенности личности.

\section{Natalia Kozlovskaya \\ PSYCHOLOGICAL AND PEDAGOGICAL FACTORS OF FORMATION OF ADOLESCENTS TO VICTIM BEHAVIOR}

The article deals with the problem of victimization and reasons behind it in adolescence. It justifies the relevance of the study of this phenomenon. The results of scientific works on the problem of victimization and victimization behavior are summarized. The results of an empirical study aimed at identifying sociopsychological determinants of the formation of a tendency to victimization in adolescence are presented. It is shown that victimization behavior occurrences in adolescents differ depending on the degree of its realization, that the tendency to victimization behavior may be due to adolescents' ideas about specific family education strategies used by parents, as well as the individual psychological characteristics of adolescents themselves on behavioral, emotional and personal levels.

Key words: victimization, the process of victimization, victimization behavior, adolescence, family education styles, individual psychological characteristics of the individual.

Bbedeнue / Introduction. Проблема виктимности подростков, то есть способности стать жертвой негативных явлений, была и остается одной из приоритетных как в зарубежных, так и в отечественных исследованиях. Во многом это обусловлено возникновением в социальных сетях групп суицидальной направленности, проявлением деструктивных взаимоотношений (буллинга) в образовательной среде, появлением так называемого кибербуллинга, то есть новой формы травли, использующей возможности интернета для агрессивного преследования человека. Эти и другие факторы могут провоцировать повышение виктимности в подростковой среде (По официальным данным, количество самоубийств с 2018 года в России составляет около 2000 человек, из которых более трети - дети и подростки.)

Проблема виктимности и виктимного поведения затрагивается в работах юристов, психологов, социологов, педагогов. Спектр исследований в данной области достаточно широк: от общетеоретических вопросов виктимности (Б. Мендельсон, Г. Гентиг, Ф. Г. Шнайдер, Л. В. Франк, Д. В. Ривман, А. Л. Репецкая, В. И Полубинский., И. Г. Малкина-Пых) до изучения особенностей виктимологической профилактики преступности (А. Б. Антонов, В. Г. Балашов, А. И. Долгова) и вопросов личной безопасности населения (Г. М. Миньковский, Е. П. Ким, А. А. Михайличенко). 
При этом данное явление в силу своей специфичности в наибольшей степени описано в криминальной виктимологии. Однако сегодня возникает необходимость перенести акцент его изучения в плоскость возрастной психологии и педагогики. Как считает О. О. Андронникова, на сегодняшний день важным направлением в исследовании виктимного поведения является изучение возрастных особенностей виктимизации, а также природы, факторов и условий развития виктимного поведения в подростковом возрасте как наиболее уязвимом к внешним и внутренним воздействиям [1;2] и потому склонном к жертвенному поведению [11].

Кроме того, X. Решмидт считает, что явное отличие данного возрастного периода от других состоит в том, что он наиболее эмоционально насыщен и характеризуется продолжительностью переживаний [11]. При этом одной из важнейших характеристик подросткового возраста, по мнению автора, является нестабильность личности, проявляющаяся в тревожности, нравственной неустойчивости, противоречивости чувств и пр.

Другие исследователи считают, что подросток наиболее подвержен риску попадания в опасные для жизни ситуации, поскольку этот возрастной период характеризуется явным различием предъявляемых требований к детям и взрослым от общества [5; 14], стремительно происходящими изменениями в психическом и физическом состоянии ребенка, которые при неблагоприятных условиях могут фиксироваться и приобретать патологические формы [4].

По мнению Д. В. Колесова и И. Ф. Мягкова, подобным неблагоприятным условием может являться накопление дефектов воспитания к подростковому возрасту [7]. К числу таких дефектов авторы относят нарушения в развитии эмоциональной сферы подростков, проявляющиеся в поверхностности чувств, быстроте их угасания, бедности эмоциональной жизни. В качестве других дефектов воспитания Д. В. Колесов, И. Ф. Мягков выделяют безответственность (неспособность или отсутствие желания подростка предвидеть и учитывать последствия своих действий), повышенную тревожность, низкую самооценку и неуверенность в себе. Подобные дефекты воспитания и прочие неблагоприятные условия развития подростка, с точки зрения авторов, могут являться истоками проявлений отклоняющегося поведения, в том числе и поведения жертвы.

Л. В. Сарафанова утверждает, что виктимизации как процессу превращения человека в жертву определенной ситуации, преступления, некоторого стечения обстоятельств подвержены те субъекты, которые внутренне не способны постоять за себя [12]. И именно подросток рискует стать жертвой таких обстоятельств, поскольку не умеет успешно ориентироваться в новых условиях, действует неосторожно и необдуманно, тем самым содействуя отрицательному развитию сложившейся ситуации.

Анализ имеющихся в данной области работ показал, что исследователи описывают разные причины возникновения виктимного поведения подростков. В частности, выделяют:

1) подростковый кризис, сопровождаемый противоречиями психического и физиологического развития, что приводит к появлению неадекватных реакций и формированию негативных установок на окружающих [9];

2) индивидуально-психологические особенности подростков, а именно: потребность в престиже и самоуважении, потребность в риске, агрессивность, эмоциональная неустойчивость, психические отклонения; неадекватная самооценка, акцентуированные черты характера $[9 ; 13]$; стремление к незнакомому, неизвестному, повышенный эгоцентризм, склонность преувеличивать проблемы, незрелость убеждений, преобладание пассивного поведения в стрессовых ситуациях и пр. [8];

3) социальный статус личности и ее психическое состояние (Л. И. Божович, Л. С. Выготский, И. Д. Бех, А. В. Фурман, К. С. Лебединская и др. - приводится по [10]); 
4) внешние признаки, в частности, физические недостатки, хронические заболевания и другие изъяны здоровья подростков (Р. Бэрон, Д. Ричардсон - приводится по [8]). Такие подростки, как считают исследователи, могут, не прилагая усилий и не желая этого, притягивать к себе опасность;

5) характеристики семьи подростка: психические особенности родителей, социально-экономический статус семьи, нормы и стиль семейного воспитания, а также те условия, в которых он живет [3; 15].

Виктимизация подростка происходит и в школе, поскольку в этом возрасте именно школа является местом постоянного активного взаимодействия ребенка со сверстниками, учителями, другими взрослыми. При этом все чаще стали говорить о таком школьном явлении, как буллинг, т. е. травля, сознательное жестокое отношение со стороны одного или группы детей по отношению к другому, что естественно превращает подростка в жертву [10].

М. А. Догадина в своих исследованиях описывает два типа жертв среди подростков: первый - тормозимый (пассивный), который характеризуется внушаемостью, нерешительностью, подчиняемостью, доверчивостью, неустойчивостью, трудностью прогнозирования последствий собственных действий; второй - возбудимый (активный), определяющийся педагогической запущенностью, несформированностью моральных установок, слабостью волевого контроля, расторможенностью [6].

Таким образом, склонность подростков к проявлению виктимного поведения может быть обусловлена целым комплексом как объективных, так и суббъективных факторов.

Материалы и методы / Materials and methods. Исходя из всего сказанного нами была сформулирована следующая цель исследования: выявление социально-психологических детерминант, оказывающих влияние на формирование склонности подростков к виктимному поведению.

Выборку составили учащиеся восьмых классов МБОУ СОШ № 9 ст. Отрадная Краснодарского края. Общее число респондентов, участвующих в исследовании, - 60 человек.

В ходе исследования были использованы:

1) методика «Склонность к виктимному поведению» О. О. Андронниковой, дающая возможность выявить целый комплекс взаимосвязанных проявлений виктимного поведения подростков и направленная непосредственно на анализ психологической реальности, скрывающейся за виктимными поведенческими аспектами;

2) методика «Родителей оценивают дети» И. А. Фурманова и А. А. Аладьина (РОД), предназначенная для изучения представлений ребенка о стиле семейного воспитания;

3) стандартизированный многофакторный метод исследования личности (СМИЛ) Л. Н. Собчик, направленный на выявление индивидуальных особенностей и психических состояний личности.

Pезультаты и обсужсдение/Results and discussion. В ходе исследования все испытуемые были разделены на три группы в зависимости от уровня предрасположенности к виктимному поведению. Первую группу составили подростки, у которых был выявлен высокий уровень склонности к виктимному поведению (18\% опрошенных), что означает, что они могут довольно часто попадать в опасные для здоровья и жизни ситуации. Вторая группа - подростки, входящие в так называемую категорию «норма» (12\% опрощенных). И в третью группу, самую многочисленную (70 \% опрошенных), вошли подростки, у которых был выявлен уровень виктимности «ниже нормы». Это означает, что такие подростки либо нечасто оказываются в кризисных ситуациях, либо стремятся их избегать. Тем не менее у них есть внутренняя готовность к виктимному поведению, т. е. они могут быть потенциально виктимными.

Анализ остальных шкал методики «Склонность к виктимному поведению» (см. рис. 1) показал, что именно для испытуемых первой группы наиболее характерно стремление к самоповреждающему или саморазрушающему поведению (9,81 стен по шкале). 


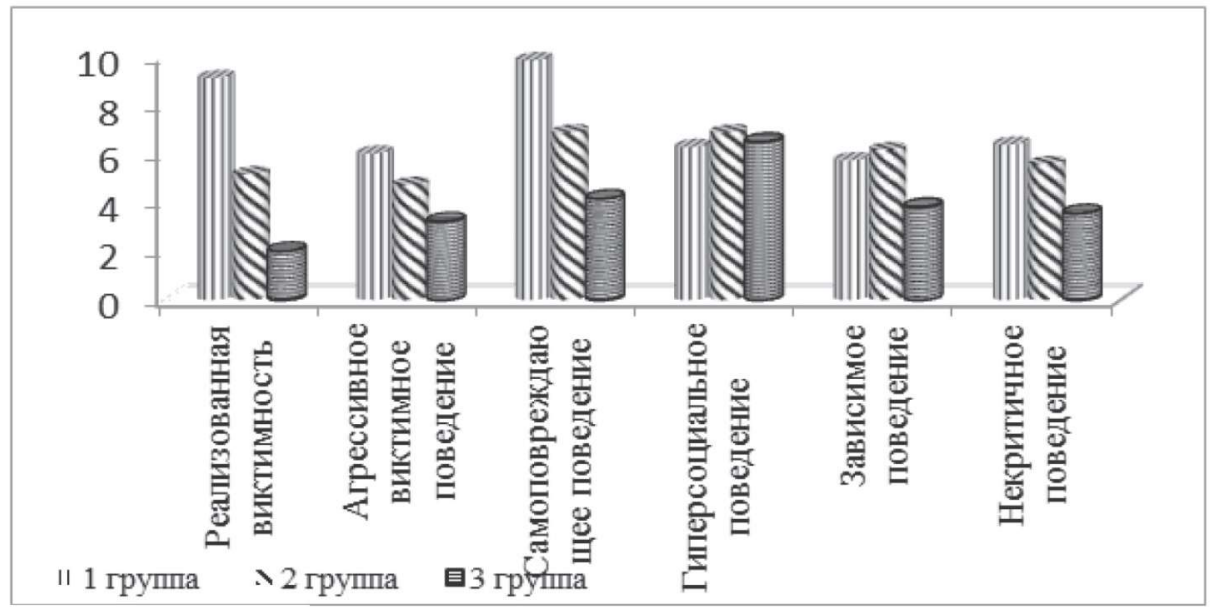

Рис 1. Результаты методики «Склонность к виктимному поведению»

В то же время испытуемые подростки с низким уровнем реализованной виктимности характеризуются, с одной стороны, отсутствием модели агрессивного виктимного поведения, наличием самоконтроля, стремлением придерживаться принятых норм и правил, а с другой стороны, неуверенностью, высоким уровнем проявления обидчивости, непримиримостью к мнению других, стремлением выделиться из толпы. Сочетание данных качеств может указывать на предрасположенность данной группы подростков к вовлечению в конфликтные ситуации, в которых будут задействованы агрессивные паттерны поведения.

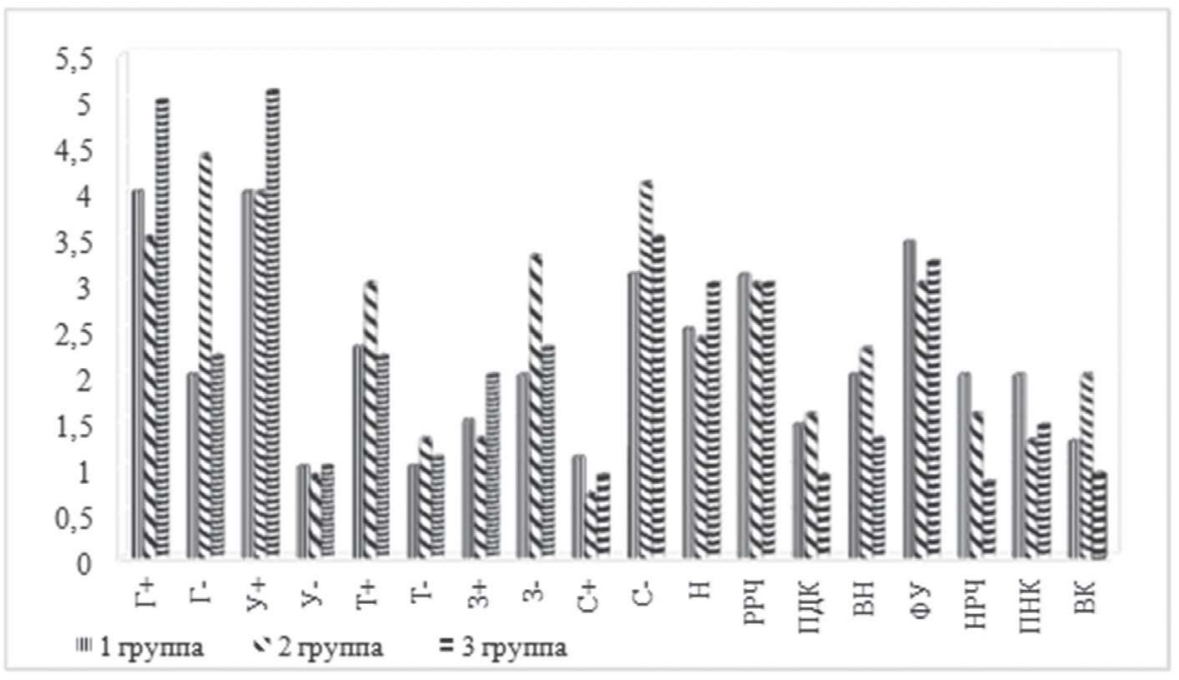

Рис. 2. Результаты методики «Родителей оценивают дети»:

Г+ - Шкала гиперпротекции; Г- - Шкала гипопротекции; У+ - Шкала потворствования; У- - Шкала игнорирования потребностей ребенка; $\mathrm{T}+-$ Шкала чрезмерности требований-обязанностей; $\mathrm{T}-\mathrm{-}$ Шкала недостаточности требований-обязанностей ребенка; 3+ - Шкала чрезмерности требований-запретов;

3- - Шкала недостаточности требований-запретов к ребенку; С+- Шкала чрезмерности санкций;

C- - Шкала минимальности санкций; Н - Шкала неустойчивости стиля воспитания; РРЧ - Шкала расширения сферы родительских чувств; ПДК - Шкала предпочтения в подростке детских качеств; ВН - Шкала воспитательной неуверенности родителя; ФУ - Шкала фобии утраты ребенка; НРЧ - Шкала неразвитости родительских чувств; ПНК - Шкала проекции на ребенка собственных нежелаемых качеств; ВК - Шкала вынесения конфликта между супругами в сферу воспитания 
Для изучения представлений испытуемых-подростков о стиле семейного воспитания как социально-психологическом факторе, способствующем виктимизации подростков, была использована методика «Родителей оценивают дети» (авторы И. А. Фурманов и А. А. Аладьин). Полученные результаты показали (рис. 2), что испытуемые, склонные к виктимному поведению, в отличие от второй и третьей групп, оценивают отношения со своими родителями как гармоничные. Однако такая оценка несколько противоречит результатам исследований, имеющимся на сегодняшний день $[2 ; 3 ; 5 ; 9 ; 10]$. Возможно, что полученный нами результат был обусловлен специфическими особенностями возраста, желанием скрыть истинное положение в семье за социально желательными ответами, демонстрацией положительной семейной атмосферы.

Кроме того, выделение в данной группе таких шкал, как «Фобия утраты ребенка (ФУ)», «Неразвитость родительских чувств (НРЧ)», «Проекция на ребенка собственных нежелаемых качеств (ПНК)», получивших наибольшую выраженность по сравнению с данными других групп, может свидетельствовать о том, что подростки, склонные к виктимному поведению, обращают внимание на такие особенности родительского воспитания и отношения к ребенку, как, с одной стороны, потворствующая гиперпротекция, а с другой - гипопротекция и эмоциональное отвержение. Можно предположить, что такие крайние и противоречивые стили воспитания могут оказывать негативное влияние на подростка и приводить к дисгармоничному развитию его личности,

У испытуемых с потенциальной виктимностью (третья группа) оказались высокие показатели по шкале «Потворствование (У+)», а также получены отличные от других групп результаты по шкале «Гиперпротекция $(\Gamma+))$, что свидетельствует о том, что в представлении испытуемых с низким уровнем реализованной виктимности их родители чрезмерно заботятся о них, слишком опекают их, удовлетворяя все потребности. Однако, как считают исследователи, в частности Э. Г. Эйдемиллер, основой гиперпротекции (сверх заботы, опеки) может стать как любовь к ребенку, так и амбивалентное к нему отношение. В некоторых случаях гиперпротекция может сочетаться с эмоциональным отвержением ребенка [15]. Мы считаем, что такое стремление родителей «привязать» к себе ребенка может стать причиной, побуждающей подростка искать и проявлять самостоятельность вне дома. Однако его неготовность к другим отношениям, его представление о себе как о человеке, которому «все должны» (он - исключительная личность для своих родителей) может привести к тому, что подросток, оказавшись в критической ситуации, будет использовать неадекватные формы поведения, что, в свою очередь, является фактором риска виктимизации.

К такому выводу нас приводит и тот факт, что у испытуемых третьей группы, в отличие от двух других, шкала «Неустойчивость стиля воспитания $(\mathrm{H}) »$ получила наибольшую выраженность. То есть испытуемые-подростки считают, что их родители, несмотря на безграничную любовь к ним, очень непоследовательны в своих действиях - они могут переходить от очень строгого стиля к либеральному, и наоборот. Данный стиль характеризует неустойчивость эмоциональных отношений в семье, что может способствовать формированию таких черт характера, как упрямство, склонность противопоставлять себя любому авторитету. На это указывает и выраженность шкалы «Чрезмерность требований-запретов» (3+), которая в этой группе также получила высокий балл, по сравнению с другими группами испытуемых. Такой стиль воспитания проявляется в том, что подросткам предъявляется большое количество требований, ограничивающих его свободу и самостоятельность, что может приводить к формированию у них либо реакции эмансипации, либо развитие сенситивной и тревожно-мнительной (психастенической) акцентуации. Кроме того, потворствующая гиперпротекция (сочетание черт, отраженных в шкалах $\Gamma+, \mathrm{У}+$ ) может способствовать развитию демонстративных (истероидных) качеств личности, что тоже является фактором, повышающим опасность виктимизации.

У испытуемых второй группы с отсутствием склонности к виктимному поведению, в отличие от первой и третьей групп, были выявлены высокие показатели по шкалам «Недостаточность запретов к ребенку (3-)», «Минимальность санкций (C-)», «Гипопротекция (Г-)». В представле- 
нии подростков данной группы родители предоставляют им свободу, не используют наказания, рассчитывают на самостоятельность ребенка, его способность адекватно реагировать на ситуацию, доверяют им. Однако подростки считают, что родители мало уделяют им внимания, им не хватает эмоционального тепла.

Необходимо отметить, что гипопротекция (гипоопека) (сочетание шкал Г-, У-, Т-, 3-) как стиль воспитания оказывается особенно неблагоприятной при акцентуациях гипертимного, неустойчивого и конформного типов (по данным методики РОД).

Для изучения индивидуальных особенностей и психических состояний личности мы использовали «Стандартизированный многофакторный метод исследования личности» (СМИЛ) Л. Н. Собчик. Анализ результатов, полученных по данной методике, показал, что все испытуемые, независимо от склонности к виктимному поведению, демонстрируют повышенные показатели по шкале «Пассивность» $(78,6$ / 78,7 / 75,1 баллов), что говорит об их пессимистичности, инертности в принятии решений, выраженной глубине переживаний, самокритичности и некоторой неуверенности в себе (рис. 3). Они могут проявлять зависимость от более авторитетной личности или объекта привязанности, и при этом для них характерно обостренное чувство собственного достоинства. В стрессовой ситуации такие подростки могут проявлять склонность к так называемым «стоп-реакциям» или ведомому поведению. Возможно, что такие проявления обусловлены спецификой возрастного развития.

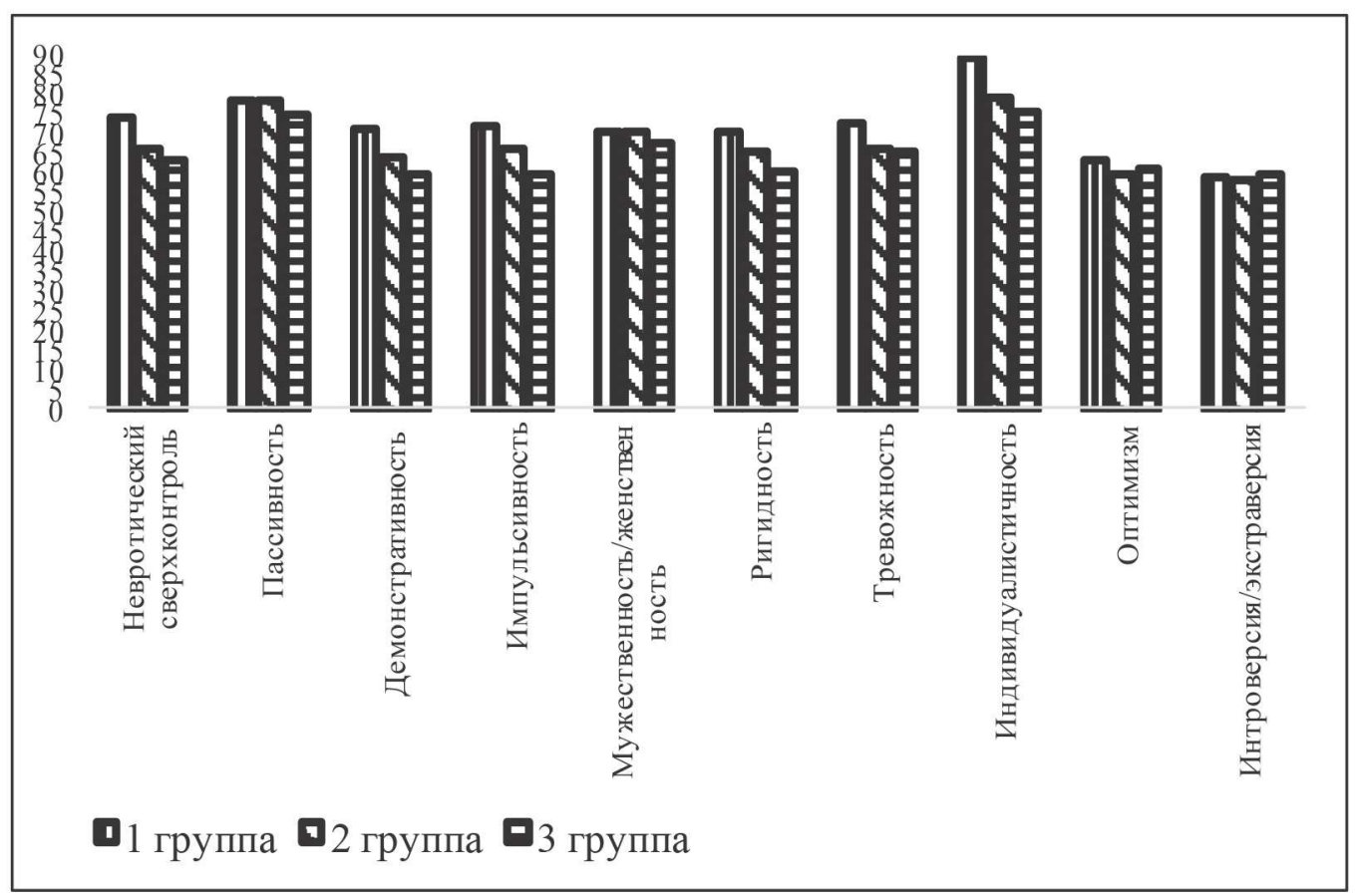

Рис. 3. Результаты по основным шкалам методики СМИЛ

У испытуемых всех групп показатели по шкале «Индивидуалистичность» также практически одинаковые (сравните: 89,7 / 79,2 / 75,7 баллов). Это может говорить о том, что данное свойство является возрастной особенностью. Однако наибольшее значение данная шкала получила в первой выборке подростков с высоким уровнем склонности к виктимному поведению. Такие подростки в повседневной жизни ориентируются в первую очередь на свою интуицию; они не воспринимают критической ситуацию, которая считается таковой для большинства лю- 
дей. В то же время ситуация, воспринимаемая ими как стресс, вызывает у них состояние сильной растерянности. А повышенные показатели по шкале «Ригидность» (71 балл) в сочетании со шкалой «Индивидуалистичность» могут свидетельствовать о наличии у испытуемых первой группы склонности к проявлению агрессивного поведения, обусловленного их восприятием мира как враждебного и несправедливого по отношению к ним, что может оправдывать их агрессивные действия в собственных глазах.

Кроме того, высокие показатели по шкалам «Демонстративность» (72 балла) и «Импульсивность» (72 балла) характеризуют данных подростков как эмоционально нестабильных, с высоким уровнем притязаний и одновременно неуверенных в себе, проявляющих демонстративность в поведении, эгоистичных, нетерпеливых, склонных к риску, агрессивных и при этом стремящихся нравиться окружающим. При этом у них отсутствует конформность, зато есть стремление к независимости, повышенная импульсивность, упрямство, что может провоцировать конфликты с окружающими. Наличие склонности таких подростков к использованию обвинений в адрес других снимает с них ответственность за сложившуюся конфликтную ситуацию.

У испытуемых первой группы с высокой склонностью к виктимному поведению также были выявлены повышенные результаты по шкалам «Невротический сверхконтроль» $(74,5$ балла) и «Тревожность» (72,97 баллов), что может свидетельствовать о наличии инертного стиля мышления, гиперсоциальных установок, которые позволяют им реализовывать собственные желания вопреки правилам и нормам. Для них также свойственно состояние дезадаптации, характеризующееся проявлением страха, чувства растерянности, беспокойства.

Сочетание выделенных шкал позволяет диагностировать у испытуемых, склонных к виктимному поведению, наличие реактивной, ситуационно спровоцированной депрессии (об этом свидетельствует выраженность пиков по 2-й и 7-й шкалам, при сопутствующем повышении 1-й, 3-й и 4-й шкал, когда 9-я шкала не ниже 40T, а 10-я не выше 65T (рис. 3). Кроме того, такое сочетание шкал может свидетельствовать о невротическом развитии личности.

Превышение всех показателей по данным шкалам у испытуемых первой группы по сравнению с остальными может указывать на то, что данные индивидуальные особенности могут быть проявлениями виктимного поведения.

Сочетание тех же шкал, степень их выраженности, позволяет охарактеризовать испытуемых второй группы как индивидов, проявляющих небольшую степень ответственности, обязательности, вдумчивых, неторопливых, практичных, не склонных к тревоге и беспокойству.

У подростков третьей группы показатели по основным шкалам: «Невротический сверхконтроль» $(63,81$ балл), «Демонстративность» $(60,25$ баллов), «Импульсивность» $(60,21$ балл), «Мужественность / Женственность» (67,61 балл), «Ригидность» $(60,45$ баллов), «Тревожность» $(65,92$ балла) также не выходят за пределы нормы, что характеризует их как субъектов с умеренным контролем эмоциональных проявлений, ориентированных на свои желания, но с учетом социальных правил, терпеливых, осторожных, с устойчивыми интересами и уверенностью в себе, что, по нашему мнению, может являться сдерживающим фактором, не позволяющим виктимности реализоваться.

Результаты по дополнительным шкалам показали следующее: у первой и третьей групп, в отличие от второй, высокие показатели были выявлены по шкалам «Подавленная агрессия» $(70,4 / 76,8$ баллов) и «Наивность» $(71,6 / 72,1$ баллов) и низкие по шкале «Интеллектуальная эффективность» $(35,1 / 33,3$ баллов), что позволяет говорить о том, что данные подростки слабо используют свои интеллектуальные ресурсы, скрывают истинные эмоции и отношение. Кроме того, они проявляют в общении доверчивость и недостаточно адаптированы в жизни.

Результаты первой группы продемонстрировали наличие высоких баллов по шкалам «Фактор паранойи» (72,4 балла), «Идеи отравления» (70,1 баллов), «Эмоциональное отчуждение» $(72,5$ баллов), «Невротизм» (73,2 балла), «Предсказание изменений» (69,1 балла), что характеризует 
испытуемых как подозрительных, с повышенным чувством тревожности, беспокойства, низкой способностью предсказания развития ситуации, неумением держать эмоциональную дистанцию с окружающими.

Проведение корреляционного анализа позволило установить положительную связь между шкалой «Реализованная виктимность» и шкалами «Гиперсоциальное поведение» $(0,38)$, «ЗЗависимое поведение» $(0,5)$, «Минимальность санкций» $(0,5)$, «Сверхконтроль Я» $(0,38)$, «Предсказание изменений» $(0,45)$, «Чистая психопатия» $(0,39)$, «Фарисейство» $(0,62)$, «Низкие способности к достижению цели» $(0,47)$; и отрицательную со шкалами: «Саморазрушающее поведение» $(-0,36)$, «Гиперпротекция» $(-0,4)$, «Чрезмерность санкций» $(-0,65)$, «Воспитательная неуверенность родителей» $(-0,5)$, «Мрачность» $(-0,5)$, «Эмоциональная незрелость» $(-0,69)$, «Интеллектуальный коэффициент» $(-0,4)$, «Осознанная выраженная враждебность» $(-0,64)$, «Ипульсивность» $(-0,5)-$ уровень значимости $\mathrm{p} \leq 0,05$ и $\mathrm{p} \leq 0,01$.

Заключение / Conclusion. Обобщая полученные результаты, мы можем констатировать тот факт, что процесс виктимизации подростков может проявляться на двух уровнях: на уровне виктимной предрасположенности и на уровне реализованной виктимности. При этом подростки с высоким уровнем реализованной виктимности проявляют склонность к самоповреждающему и саморазрушающему поведению, а подростки с низким уровнем реализованной виктимности, несмотря на отсутствие модели агрессивного виктимного поведения и хороший самоконтроль, а также стремление придерживаться принятых норм и правил, из-за неуверенности и высокой обидчивости оказавшись в конфликтной ситуации, могут использовать агрессивные паттерны поведения.

В ходе исследования было установлено, что реализация виктимного потенциала в виде поведения может быть обусловлена стилем семейного воспитания, отношением родителей к подростку. Использование родителями потворствующей гиперпротекции одновременно с гипопротекцией, а также наличие эмоционального отвержения способствуют формированию высокого уровня реализованной виктимности, приводя к дисгармоничному развитию личности. В то же время формирование виктимного потенциала может быть обусловлено, с одной стороны, гиперопекой, приводящей к развитию эгоцентричности подростка, веры в свою исключительность, a c другой - непоследовательностью поведения родителей, неустойчивостью эмоциональных отношений в семье. При этом потворствующая гиперпротекция как стиль родительского воспитания может способствовать развитию демонстративных качеств личности и приводить к риску виктимизации, в то время как невиктимное поведение обусловлено выбором адекватных способов взаимодействия с подростками, учетом их возрастной специфики, предоставления самостоятельности, построением партнерских отношений с детьми, выбором адекватных ситуации способов воздействия.

Было также выявлено, что склонность к виктимному поведению может быть обусловлена сформированностью таких психологических качеств, как отсутствие конформности, стремление к независимости, повышенная импульсивность, упрямство, инертность и некритичность мышления, тревожность, эмоциональная незрелость, импульсивность, эмоциональная отчужденность, пассивность, индивидуалистичность, доверчивость. Кроме того, реализация виктимного поведения подростков обусловлена низкой социальной лабильностью, определяющей их неспособность понимать других людей и учитывать особенности ситуации взаимодействия, а также низкой способностью предсказания развития ситуаций и сохранения эмоциональной дистанции с окружающими. Наконец, можно утверждать, что к реализации виктимного потенциала в виде поведения приводит присутствие ряда факторов: так, для реализованной виктимности характерно наличие реактивной, ситуационно спровоцированной депрессии и невротического развития личности, в то время как для потенциальной виктимности - наличие подавленной агрессии, доверчивости, слабой адаптированности подростков к реальным условиям жизни. 


\section{ЛИТЕРАТУРА И ИНТЕРНЕТ-РЕСУРСЫ}

1. Андронникова О. О. Основные характеристики подростков с самоповреждающим виктимным поведением // Вестник ТГПУ. 2009. Выпуск 9 (87). С. 21-32.

2. Андронникова О. О. Психологические факторы возникновения виктимного поведения подростков: дис. ... канд. психол. наук. Новосибирск, 2005. 213 с. URL: http://www.dissercat.com/content/ psikhologicheskie-faktory-vozniknoveniya-viktimnogo-povedeniya-podrostkov (дата обращения: 18.10.2018).

3. Андронникова О. О. Роль семьи в формировании неадаптивных форм виктимного поведения детей // Семья в XXI веке: сб. мат-лов Международного экспертного симпозиума. Новосибирск, 2013. С. 156-164.

4. Аракелов Г. Г., Жариков Н. М., Зеер Э. Ф. Учителям и родителям о психологии подростка. М.: Высш. шк., 1990. 303 c. URL: http://born.elimash.ru/jurnaly/book-1420.html (дата обращения: 21.10.2018).

5. Волянюк Н. Ю., Ложкін Г. В., Папуша В. В. Віктимологія та агресологія: навчальний посібник. Рівне: Прінт Хауз, 2010. 265 c.

6. Догадина М. А., Пережогин Л. О. Сексуальное насилие над детьми. Выявление, профилактика, реабилитация потерпевших // Вопросы ювенальной юстиции. 2009. № 3 (22). С. 3-8.

7. Колесов Д. В., Мягков И. Ф. Учителю о психологии и физиологии подростка. М.: Просвещение, 1986. 80 c. URL: http://author-club.org/shop/products/562/ (дата обращения: 10.09.2018).

8. Крайг Г. Психология развития. СПб.: Питер, 2002. 992 c. URL: https://www.psyoffice.ru/3340-krajjggrjejjs.-psikhologija-razvitija..html (дата обращения: 15.09.2018).

9. Матанцева Т. Н. Факторы виктимного поведения подростков как социальная проблема психологической науки // Концепт: научно-методический электронный журнал. 2016. Т. 8. С. 74-81.

10. Михайлюк Е. Б. Социально-психологические факторы формирования виктимного поведения несовершеннолетних // Северо-Кавказский психологический вестник. 2011. № 9 (1). С. 45-48.

11. Ремшмидт Х. Подростковый и юношеский возраст. Проблемы становления личности. М.: Мир, 1994. 320 c. URL: https://www.twirpx.com/file/477705 (дата обращения: 30.10.2018).

12. Сарафанова Л. В. Процесс виктимизации подростков и педагогические возможности его предупреждения // Вестник ТГУ. 2012. Вып. 3. С. 157-161.

13. Фельдман Д. В. Теоретико-методологические основы изучения социально-психологических условий влияния стратегии жизни на уровень виктимности молодежи // Социальная политика и социология. 2012. № 8. С. 236-254.

14. Шнейдер Л. Б. Девиантное поведение детей и подростков. М.: Академический Проект; Трикста, 2005. $336 \mathrm{c}$.

15. Эйдемиллер Э. Г., Юстицкис В. Психология и психотерапия семьи. СПб.: Питер, 2008. 672 с. URL: http://www.klex.ru/9cf (дата обращения: 25.09.2018).

\section{REFERENCES AND INTERNET RESOURCES}

1. Andronnikova $\mathrm{O}$. O. Osnovnye kharakteristiki podrostkov $\mathrm{s}$ samopovrezhdayushchim viktimnym povedeniem (The main characteristics of adolescents with self-damaging victimization behavior) // Vestnik TGPU. 2009. Vypusk 9 (87). S. 21-32.

2. Andronnikova O. O. Psikhologicheskie faktory vozniknoveniya viktimnogo povedeniya podrostkov (Psychological factors of victimization behavior of adolescents): dis. ... kand. psikhol. nauk. Novosibirsk. 2005. 213 p. URL: http://www.dissercat.com/content/psikhologicheskie-faktory-vozniknoveniyaviktimnogo-povedeniya-podrostkov (data obrashcheniya: 18.10.2018).

3. Andronnikova O. O. Rol' sem'i v formirovanii neadaptivnykh form viktimnogo povedeniya detei (The role of the family in the formation of non-adaptive forms of victimization behavior of children) // Sem'ya $\mathrm{v}$ KhKhI veke: sb. mat-lov Mezhdunarodnogo ekspertnogo simpoziuma. Novosibirsk, 2013. S. 156-164.

4. Arakelov G. G., Zharikov N. M., Zeer E. F. Uchitelyam i roditelyam o psikhologii podrostka (Teachers and parents about teen psychology). M.: Vyssh. shk., 1990. 303 s. URL: http://born.elimash.ru/jurnaly/book1420.html (data obrashcheniya: 21.10.2018).

5. Volyanyuk N. Yu., Lozhkin G. V., Papusha V. V. Viktimologiya ta agresologiya (Viktimologiya and agresologiya): navchal'nii posibnik. Rivne: Print Khauz, 2010. 265 s. 
6. Dogadina M. A., Perezhogin L. O. Seksual'noe nasilie nad det'mi. Vyyavlenie, profilaktika, reabilitatsiya poterpevshikh (Child sexual abuse. Identification, prevention, rehabilitation of victims) // Voprosy yuvenal'noi yustitsii. 2009. No 3 (22). S. 3-8.

7. Kolesov D.V. Uchitelyu o psikhologii i fiziologii podrostka (Teacher about the psychology and physiology of a teenager) / D.V. Kolesov, I.F. Myagkov. M.: Prosveshchenie, 1986. 80 p. URL: http://author-club.org/ shop/products/562/ (data obrashcheniya: 10.09.2018).

8. Kraig G. Psikhologiya razvitiya (Developmental psychology). SPb.: Piter, 2002. 992 p. URL: https://www. psyoffice.ru/3340-krajjg-grjejjs.-psikhologija-razvitija.html (data obrashcheniya: 15.09.2018).

9. Matantseva T. N. Faktory viktimnogo povedeniya podrostkov kak sotsial'naya problema psikhologicheskoi nauki (Victim behavior factors of adolescents as a social problem of psychological science) // Kontsept: nauchno-metodicheskii elektronnyi zhurnal. 2016. T. 8. S. 74-81.

10. Mikhailyuk E. B. Sotsial'no-psikhologicheskie faktory formirovaniya viktimnogo povedeniya nesovershennoletnikh (Socio-psychological factors in the formation of victimization behavior of minors) // Severo-Kavkazskii psikhologicheskii vestnik. 2011. No 9 (1). S. 45-48.

11. Remshmidt Kh. Podrostkovyi i yunosheskii vozrast. Problemy stanovleniya lichnosti (Teenage and youthful age. Problems of the formation of personality.). M.: Mir, 1994. 320 p. URL: https://www.twirpx.com/ file/477705 (data obrashcheniya: 30.10 .2018 )

12. Sarafanova L. V. Protsess viktimizatsii podrostkov i pedagogicheskie vozmozhnosti ego preduprezhdeniya (The process of victimization of adolescents and the pedagogical possibilities of its prevention) // Vestnik TGU. 2012. Vyp. 3. S. 157-161.

13. Fel'dman D.V. Teoretiko-metodologicheskie osnovy izucheniya sotsial'no-psikhologicheskikh uslovii vliyaniya strategii zhizni na uroven' viktimnosti molodezhi (Theoretical and methodological foundations of the study of the socio-psychological conditions of the influence of life strategies on the level of victimization of young people) // Sotsial'naya politika i sotsiologiya. 2012. No 8. S. 236-254.

14. Shneider L. B. Deviantnoe povedenie detei i podrostkov (Deviant behavior of children and adolescents). M.: Akademicheskii Proekt; Triksta, 2005. 336 s.

15. Eidemiller E. G., Yustitskis V. Psikhologiya i psikhoterapiya sem'I (Family psychology and psychotherapy). $\mathrm{SPb}$ : Piter, 2008. 672 s. URL: http://www.klex.ru/9cf (data obrashcheniya: 25.09.2018).

\section{СВЕДЕНИЯ ОБ АВТОРЕ}

Козловская Наталья Владимировна, кандидат психологических наук, доцент, доцент кафедры психологии, Институт образования и социальных наук СКФУ. E-mail: natalya-kozlovsk@mail.ru

\section{INFORMATION ABOUT AUTHOR}

Kozlovskaya Natalia Vladimirovna, Candidate of Psychological Sciences, Assistant Professor, Associate Professor of the Department of Psychology, Institute of Education and Social Sciences NCFU. E-mail: natalyakozlovsk@mail.ru 